Archives of Agriculture and Environmental Science

\title{
Comparative study of some indigenous crops with cereals (wheat and rice) in hilly areas of Uttarakhand (Western Himalaya) with special reference to their nutrients
}

\section{P.S. Chauhan}

Tree Biology Laboratory, Department of Botany, Govt. P.G. College Gopeshwar, Chamoli, (Uttarakhand), INDIA

E-mail:drpschauhan17@gmail.com

\section{ARTICLE HISTORY}

Received: 01 October 2018

Revised received: 26 October 2018

Accepted: 22 November 2018

\section{Keywords}

Carbohydrates and nutrition

Indigenous crops

Migration

Nutrients composition

Setaria italic

Western Himalaya

\begin{abstract}
Traditional crops were frequently cultivated before two decades in hilly areas of Uttarakhand and economy of the local peoples depends on the production of these crops. But now a day's migration and climate change is two major problems which affecting the farming system of these crops. When people migrate, their lands quickly turn barren because weeds and shrubs take root and are difficult to remove. Even peoples who are staying there, they are not interested to do the farming of such crops due to typical geographical situation. They depend on market for rice and wheat. Some indigenous crops i.e. A. hypochondriacus, E. coracana, E. frumentacea, S. italica and F. tataricum were selected for the present investigation. Chemical compositions i.e. protein, carbohydrates, mineral, fiber etc. of all the selected crops have been analyzed and their nutrient percentage was compared with rice and wheat. Study showed that the nutrition percentage in indigenous crops was higher than rice and wheat. Maximum $410 \pm 22.0$ kilo calorie energy was observed in A. hypochondriacus in comparison to wheat $(346 \pm 21.34)$ and rice $(345 \pm 21.33)$. Calcium $(222 \pm 11.78 \mathrm{mg} / 100 \mathrm{gm})$ and iron percentage $(13.9 \pm .99 \mathrm{mg} / 100 \mathrm{gm})$ was also higher recorded in same crop. However protein percentage in $F$. tataricum was higher $(12 \pm .98 \mathrm{gm} / 100 \mathrm{gm})$ in comparison to wheat $(11.8 \pm .97)$ and rice $(6.8 \pm .09 \mathrm{gm} / 100 \mathrm{gm})$. Overall higher nutrient content was recorded in selected millets in comparison to wheat and rice.
\end{abstract}

(C)2018 Agriculture and Environmental Science Academy

Citation of this article: Chauhan, P.S. (2018). Comparative study of some indigenous crops with cereals (wheat and rice) in hilly areas of Uttarakhand (Western Himalaya) with special reference to their nutrients. Archives of Agriculture and Environmental Science, 3(4): 407-409, https://dx.doi.org/10.26832/24566632.2018.0304013

\section{INTRODUCTION}

Nutrition is the most important source for maintaining human health and complete physical well being. Since nutrition well being is the driving force for development and maximization of human genetic potential (Radhica et al., 2011). Millets have many nutritional properties that are helpful to prevent many health problems such as lower blood pressure, risk of heart disease, prevention of cancer and cardiovascular diseases etc. Other health benefits are increasing the time span of gastric emptying, provides roughage to gastro intestine (Gupta et al., 2012). It is very important crop with following characteristics: it is known to drought resistant crop, resistance to pests and disease, short growing season as compared to other major cereals (ICRISAT, 2007). In addition to be nutritionally rich, the advantage of growing millets is that it as a rain fed crop which forms part of a multi-cropping system, in the since that it is mostly grown along with legumes and oilseed (Chopra and Neelam, 2004; Pradhan et al., 2010). Millets, referred to as ancient grain is an ideal example of such crop. Archaeologist estimate that the cultivation of millet began in the Korean Peninsula before 300 BC (Crawford and Lee, 2003). The aim of present study is carried out to observe the biochemical nutrients in some local crops and their nutrient content compare with wheat and rice. Actually agriculture is the main source of livelihood in hilly areas of Uttarakhand. Many people may choose to stay in the hills and do agriculture. These are too much hard work in agriculture but not much gain because no 
proper irrigation sources available in hills. People of hilly areas farming only wheat and rice as cereals with low production and recently they rejected millets crops. However, nutritional point of view only millets are the rich source of different nutrients for local people (Devi et al., 2014). Thus, the present investigation was planned to compare some indigenous crops with cereals (wheat and rice) in hilly areas of Uttarakhand (Western Himalaya) with special reference to their nutrients.

\section{MATERIALS AND METHODS}

Study has been carried out in Chamba block of district Tehri Garhwal in Uttarakhand state. Eight villages i.e. Kyari, Dharsal gaon, Kanda, Sudada, Budogi, Kuttha, Faugul and Palam were selected for study area and some indeginous crops i.e. Amarantus hypochondriacus, Eleusine coracana, Echinochloa frumentacea, Fagopyrum tataricum and Setaria italica have been selected for the present investigation. Wheat and rice seeds were also collected from the above selected villages. Sample of all applied crops has been collected from the villagers. Collected seeds samples categorised in two sets one set have referred to GB Pant University, Uttarakhand for biochemical analysis while another set of experimentation analysed in tree biology laboratory of the department of botany. Nutrients contents i.e. protein, fat, fibre minerals etc. of such applied crops compared with wheat and rice.

\section{RESULTS AND DISCUSSION}

The significant results of all applied crops have been observed and their nutrient percentage was compared with wheat and rice (Tables 1, 2). Maximum (15.6 \pm 1.02$)$ protein percentage was recorded in Amarantus hypochondriacus in comparison to wheat (11.8 \pm .97). It is important source of protein, which is highly digestible and is an excellent source of dietary fibre with good amounts of soluble and insoluble fractions (Veena et al., 2005). Fat percentage was also higher $(6.3 \pm .03)$ in same crop in comparison of rice $(0.5 \pm .0002)$ and wheat (1.5 \pm .003$)$. Fagopyrum tataricum was found most effective in fibre content and it was maximum (10.3 \pm .96$)$. Thus the millet grain have good amount of fibre as compared to the rice. Minerals percentage was higher

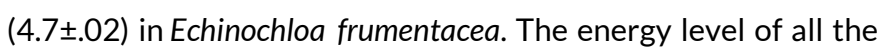
applied crops also been recorded (Figure 1). A maximum energy level 410 kilo calorie was observed in A. hypochondriacus which is followed by Setaria italica $(60.90 \pm 5.94)$ in comparison to rice

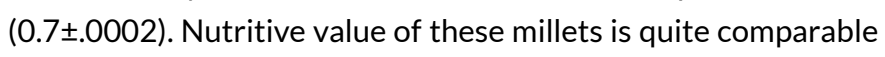
to wheat and rice. Millets are unique among the cereals because of their richness in calcium, dietary fibre, polyphenols and protein (Devi et al., 2014). Higher energy level was noticed in all the applied crops in comparison to wheat and rice. Eleusine coracana and $A$. hypochondriacus showed maximum calcium percentage (Figure 2) however, minimum was recorded in rice (10\%). The calcium of barnyard millet as 20mg/100gm (Gopalan et al., 2007) and other millet and rice as $10.0 \mathrm{mg} / 100 \mathrm{gm}$ (Yadav et al., 2007). Lysine and iron percentage was higher noticed in all the tested crops but iron \% was noticed least in E. coracana in comparison to wheat and rice (Table 2). Millets contain higher quantity of essential amino acids methionine and cytosine and are higher in fat content than maize, rice and sorghum (Kamara et al., 2009). The iron content of E. frumentacea was found higher $18.6 \pm 1.78 \mathrm{mg} / 100 \mathrm{gm}$ which is followed 3.9 in E. coracana. E. coracana is good source of amino acids except lysine and threonine but are relatively high in sulphur containing amino acids methionine and cysteine (Singh and Mishra, 2012). Significant amount of sulphur containing essential amino acids like methinine and cysteine are reported in millets (Obilana and Manyasa, 2002). Millets have also nutraceutical properties in the form of antioxidants which prevent deterioration of health (Rao et al., 2011).

Table 1. Nutrients (gm/100gm) present in different millets in comparison of wheat (T. aestivum) and rice (O. sativa).

\begin{tabular}{lllllllc}
\hline \multirow{2}{*}{ Nutrients } & \multicolumn{3}{c}{ Millets } & \multicolumn{2}{c}{ Cereals } \\
\cline { 2 - 7 } & A.hypochondriacus & E. coracana & E. frumentacea & F. tataricum & S. italica & T.aestivum & O. sativa \\
\hline Protein & $15.6 \pm 1.02$ & $7.3 \pm .08$ & $6.2 \pm .02$ & $12.0 \pm .98$ & $5.8 \pm .04$ & $11.8 \pm .97$ & $6.8 \pm .09$ \\
Fat & $6.3 \pm .03$ & $1.3 \pm .002$ & $5.8 \pm .04$ & $2.4 \pm .008$ & $4.3 \pm .01$ & $1.5 \pm .003$ & $0.5 \pm .0002$ \\
Fibre & $2.4 \pm .02$ & $3.6 \pm .03$ & $9.8 \pm .09$ & $10.3 \pm .96$ & $14 \pm 1.0$ & $1.2 \pm .001$ & $0.2 \pm .0001$ \\
Minerals & $2.9 \pm .06$ & $2.7 \pm .007$ & $4.7 \pm .02$ & $2.9 \pm .009$ & $3.3 \pm .09$ & $1.5 \pm .008$ & $.07 \pm .0003$ \\
\hline
\end{tabular}

\pm SE of means

Table 2. Lysine and Iron (mg/100gm) present in different millets in comparison of wheat (T. aestivum) and rice (O. sativa).

\begin{tabular}{|c|c|c|c|c|c|c|}
\hline \multirow[b]{2}{*}{ A. hypochondriacus } & \multicolumn{2}{|c|}{ Millets } & \multirow[b]{2}{*}{ F. tataricum } & \multirow[b]{2}{*}{ S. italic } & \multicolumn{2}{|c|}{ Cereals } \\
\hline & E. coracana & E. frumentacea & & & T. aestivum & O. sativa \\
\hline Lysine $5.5 \pm .21$ & $3.5 \pm .03$ & $16.6 \pm 1.03$ & $6.2 \pm .03$ & $14.7 \pm 1.01$ & $2.9 \pm .06$ & $3.7 \pm .08$ \\
\hline 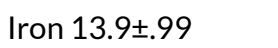 & $3.9 \pm .07$ & $18.6 \pm 1.78$ & $13.2 \pm .99$ & $17.5 \pm 1.44$ & $3.5 \pm .03$ & $1.8 \pm .003$ \\
\hline
\end{tabular}




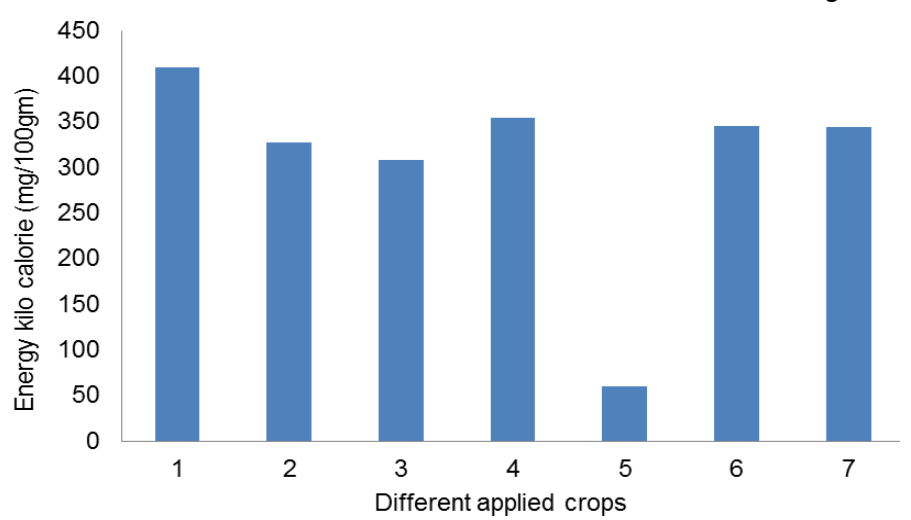

Figure 1. Energy kilo calorie $(\mathrm{mg} / 100 \mathrm{gm})$ present in different applied crops (1-A. hypochondriacus, 2-E. coracana, 3-E. frumentacea, 4-F. tataricum, 5-S. italica) in comparison of 6-T. aestivum and 7-O. sativa.

\section{Conclusion}

Studied crops are underutilized and neglected in the hills area because of little knowledge to people and some critical problem like lower cooking quality, taste and low bioavailability. Study showed that need to millet farming properly and regularly, by the local peoples and it could be beneficial for him. Millets crops may generate the income sources and peoples no need to go outside from the village for money. Even regular use of millets gets free from diseases.

Open Access: This is an open access article distributed under the terms of the Creative Commons Attribution 4.0 License, which permits unrestricted use, distribution, and reproduction in any medium, provided the original author(s) if the sources are credited.

\section{REFERENCES}

Chopra, K. and Neelam, M. (2004). Common health problems encountered by the tribal community in Bastar district. Health and population- Perspectives and Issues, 27(1): 40-48.

Crawford and Lee, G.A. (2003). Agricultural origins in the Korean peninsula. Cambridge Journal of Antiquity, 77: 87-95.

Devi, P.B., Vijayshrithy, R., Salhgabama, S., Malleshi, N.G. and Priyadarisini, V.B. (2014). Health benefits of finger millet (Elucine coracana) polyphenols and dietary fibre: A review. Journal of Food, Science and Technology, 51(6):1021-1040, https://doi.org/10.1007/s13197-011-0584-9

Gopalan, C., Ramasatri, B.V. and Balasubraman, S.C. (2007). Nutritive value of Indian foods, Hyderabad, NIN, ICMR, pp. 204

Gupta, N., Srivastava, A.K. and Pandey, V.N. (2012). Biodiversity and nutritional quality of some Indians millets. Proceeding of the national academy of sciences, India section B:

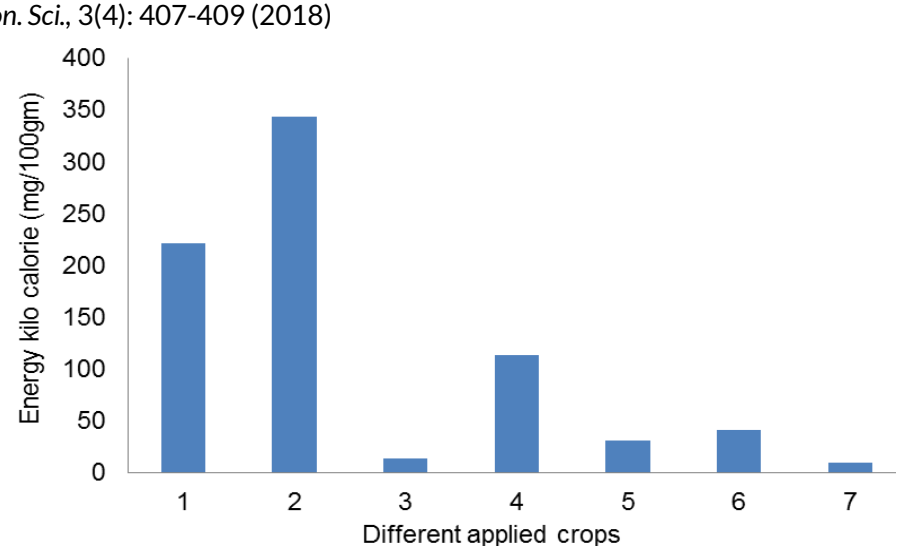

Figure 2. Calcium percentage $(\mathrm{mg} / 100 \mathrm{gm})$ present in different applied crops (1-A. hypochondriacus, 2-E. coracana, 3-E. frumentacea, 4-F. tataricum, 5-S. italica) in comparison of 6-T. aestivum and 7-O. sativa.

Biological Science, 82(2): 265-273.

ICRISAT (2007). ICRISAT Annual Report 2007 'New Horizons of Scientific Excellence for the Semi-Arid Tropics'. International Crops Research Institute for the Semi-Arid Tropics, Patancheru, Hyderabad, India, pp. 52.

Kamara, M.T., Ming, Z.H. and Kexue, Z. (2009). Extraction characterization and nutritional properties of two varites of defatted foxtail millet flour (Setaria italic L.) grow in China. Asian Journal of Biochemistry, 4: 88-98.

Obilana, A.B. and Manyasa, E. (2002). Psedocereals and less common cereals. Grain properties and utilization potential. In: PS Belton \& JRN Taylor (Eds.). Springer-verlag: New York pp. 177- 217.

Pradhan, A., Nag, S.K. and Patil, S.K. (2010). Dietary management of finger millet. Current Science, 98(6): 763-765.

Radhica, G., Sathya, R.M., Ganesen, A., Saroja, R., Vijaylaxmi, P. and Sudha, A. (2011). Dietary profile of urban adult population in south India in the context of chronic disease epidemiology (CURES-68). Journal of Public Health Nutrition, 14(4): $\quad$ 591-598, https://doi.org/10.1017/ S136898001000203X

Rao, B.R., Nagasampgie, M.H. and Ravikiran, M. (2011). Evaluation of nutraceutical properties of selected small millets. Journal of Pharma and Bioallied Science, 3(2):277-279, https://doi.org/10.4103/0975-7406.80775

Singh, K.P. and Mishra, H.N. (2012). Fuzzy Analysis of sensory attributes of bread prepared from millet-based composite flours. LWT-Food Science and Technology, 48:276-82.

Veena, B., Chimad, B.V., Naik R.K. and Shanta Kumar G. (2005). Physiochemical and nutritional studies in barnyard millet. Karnataka Journal of Agriculture, 18(1): 101-105.

Yadav, R.B., Khatkar, B.S. and Yadav, B.S. (2007). Morphological, physiochemical and cooking properties of some Indian rice (Oryza sativa) cultivars. Journal of Agriculture Technology, 3 (2): 203-210. 